THE IMPACT OF TECHNOLOGY INTERMEDIARIES ON FIRM COGNITIVE CAPACITY ADDITIONALITY

\author{
Mirjam Knockaert (corresponding author) \\ University of Ghent \\ Tweekerkenstraat 2 \\ 9000 Gent \\ Belgium \\ and University of Oslo \\ Centre for Entrepreneurship \\ Norway \\ Mirjam.knockaert@ugent.be \\ tel: 003292643459 \\ fax: 003292647888 \\ $\&$ \\ André Spithoven \\ Belgian Science Policy Office and University of Ghent \\ Avenue Louise 231 \\ 1050 Brussel \\ Belgium \\ $\&$ \\ Bart Clarysse \\ University of Ghent and Imperial College Business School \\ Tweekerkenstraat 2 \\ 9000 Gent \\ Belgium
}




\title{
THE IMPACT OF TECHNOLOGY INTERMEDIARIES ON FIRM COGNITIVE CAPACITY ADDITIONALITY
}

\begin{abstract}
Whereas the provision of $R \& D$ subsidies has been central to public policy for many years, governments have recently become increasingly involved in stimulating cooperation for innovation and R\&D. In many countries, financial support for technology intermediaries has become one of the key measures of indirect public support. However, little research has assessed the impact of indirect policy measures. In this paper, we shed light on the conditions under which technology intermediaries contribute to knowledge and networking outcomes generated by the firms that call upon them. We hereby focus on firm network and competence additionality as measures for cognitive capacity additionality and study the impact of technology intermediaries on firms. In doing so, we distinguish between $R \& D$ and $R \& D$ related activities technology intermediaries engage in. The results indicate that absorptive capacity of the technology intermediary does not affect cognitive capacity additionality generated by firms in R\&D activities, while the results for $R \& D$ related activities are mixed and depending on the type of cognitive capacity additionality studied. The absorptive capacity of firms does not directly affect cognitive capacity additionality, but the results of mediation analysis show that firms with higher levels of absorptive capacity use the services of the technology intermediary more intensively, and subsequently generate higher levels of cognitive capacity additionality.
\end{abstract}

Keywords: technology intermediary, absorptive capacity, cognitive capacity additionality 


\section{Introduction}

Over the previous decades, governments worldwide have been active in drawing policy measures oriented towards the stimulation of $R \& D$. The main rationale for governments to intervene in innovation and $R \& D$ is the existence of a market failure [1]. According to this rationale firms under invest in innovation as they are unable to appropriate all the benefits arising from innovative activities [2-4]. In such circumstances, governments may be better endowed with abilities to shoulder risks related to $R \& D$ activity than individual firms as they have the means to enhance the appropriability of R\&D investments [5]. Along the same lines, Dalziel [6] refers to the existence of an innovation gap in which firms are reluctant to invest in $R \& D$ due to the ever-increasing pressures to deliver measurable results. By consequence, the innovation gap refers to the disparity in goals and performance measures of the business and research communities.

There are many ways in which governments can help to mitigate the existence of this market failure. Traditionally, governments engage in the provision of direct incentives for $\mathrm{R} \& \mathrm{D}$, such as R\&D subsidies, government tax credits and loans. More recently, however, it has become clear that market failure increasingly relates to the transfer and flows of information between firms or between firms and public research organizations than to the production of $R \& D$ as such. This is confirmed by the observation made by many authors [79] that success of firms, and especially Small and Medium Enterprises (SMEs), will be dependent on their ability to utilize external networks efficiently. According to Mowery [10], as a result, public policy will engage in promoting transfer of knowledge through networking and collaborative R\&D programs, since costs of transferring and exploiting scientific and technological knowledge are high. This was confirmed by Autio et al. [1] observing that policy initiatives are progressing and moving away from $R \& D$ subsidies towards initiatives promoting externalities that facilitate firm-level innovation and learning outcomes [11-13]. They argue that the rationale of governments to do so is related to the recognition of the 
importance of knowledge spill-overs as a facilitator for innovation [1]. Furthermore, by engaging in indirect policy initiatives, governments try to overcome 'network failure' which occurs when the activities of different actors are poorly coordinated following a lack of interaction [1]. Indirect policy measures include the financing of science parks, incubation centres, business network initiatives and technology intermediaries, amongst others.

As a result of political choices which have, until recently, focused on direct R\&D mechanisms, research on the efficiency and effectiveness of public financing has mainly focused on the analysis of direct R\&D promotion mechanisms. David et al. [14], Hsu et al. [15], Koga [16] and Clarysse et al. [17] for instance analyzed the impact of R\&D subsidies, whereas Hall and Van Reenen [18] studied the impact of fiscal incentives and Lee [19] studied the impact of R\&D tax credits, grants and loans. The few studies that have assessed the impact of indirect $R \& D$ related measures have focused on output-related measures, such as firm performance [20]. Exceptions are the study by Davenport et al. [21] who studied a New Zealand government scheme sponsoring collaborative research and the study by Autio et al. [1] who studied intermediate results of collaborative R\&D programs by assessing the extent to which collaborative $R \& D$ programs enhanced firms' identification with a community of practice. Our study complements these studies by analyzing the intermediate output linked to the generation of knowledge and networking at firm level, generated through interaction with a specific and under studied type of indirect R\&D support mechanism, namely technology intermediaries.

Technology intermediaries may facilitate the interaction between different organizations. They are involved in a wide range of activities such as knowledge brokerage, diffusion of new ideas, boundary spanning activities,...(we refer to Howells [22] for an excellent overview of technology intermediary activities). These intermediaries have received attention by scholars in technology transfer, innovation management, innovation systems and service innovation (Howells [22]). According to Dalziel [6], these intermediaries are 
organizations that purposefully position themselves in the innovation gap. Technology intermediaries are often framed in an industry-level analysis in which innovation systems, constituent sectors and their boundaries are central [23-24] and in which they are instrumental in the mission of technology transfer [25-26]. Even though technology intermediaries have existed for many years, they remain relevant mechanisms in recent times characterized by open innovation [27-28] and open source technological developments [29]. To our knowledge, no research has studied the extent to which technology intermediaries succeed in their main mission of technology and knowledge transfer and network creation. This study, therefore, does not focus on the output effects of technology intermediary-firm interaction but studies the intermediate results linked to network and knowledge generation. Specifically, this study analyzes the extent to which firm-technology intermediary interaction results in cognitive capacity additionality, uniting network and competence additionality. Cognitive capacity additionality occurs when new partnerships are built and competences of actors are enforced [30-31].

This study builds upon interviews carried out with the managers of technology intermediaries, namely the twelve collective research centres in Belgium, and the results of a survey conducted with their member firms. These centres are private initiatives allowed by policy in the aftermath of the Second World War which were, initially, created to encourage scientific and technological research in sectors of the economy to improve productivity, quality and production. Although collective research centres are unique actors, the results of this research are representative for other technology intermediaries. For instance, we found the functioning of the "Centres Techniques Industriels" in France to be quite similar to that of the collective research centres.

In what follows, we first provide an overview of the origin, definition and use of the concept of cognitive capacity additionality, which is a subdimension of behavioural additionality, followed by an elaboration of the theoretical framework used and present our 
conceptual framework. Next, we provide an overview of the methodology used. We subsequently elaborate on the research results. Finally, we present conclusions and directions for further research.

\section{Origin, definition and use of cognitive capacity additionality}

The concept of additionality originally rests on the neo-classical market failure rationale [32], and has gained importance over the past decades [2]. Following the study by Buisseret et al. [33], Falk [30] indicates that several additionality concepts can be used to measure the effects of public assistance on firms' innovation activities. The author classifies these concepts in three broad categories: resource-based concepts, result-based concepts and concepts that measure the success of policy intervention by examining desirable changes in the process of innovation. The most refined of the resource-based concepts is input additionality which measures whether, and to which extent, firms increase their private spending on innovation-related activities when supported, i.e. whether the firm itself spends at least one additional Euro on the research project for every Euro received in subsidy. Output additionality, as a result-based concept, deals directly with the most decisive impact, and is either defined in terms of marketable output (e.g. patents or successful innovations) or commercial outputs (e.g. sales or profits). While input and output additionality have received quite some attention over the past decades (e.g. the studies by Hewitt-Dundas and Roper [34], Aerts and Schmidt [35]), only recently researchers focused on a third type of additionality, namely "behavioural" additionality. Behavioural additionality indicates whether there was a change in the behaviour of the firm resulting from the intervention [36]. Behavioural additionality may include scope additionality, cognitive capacity additionality and acceleration additionality. Scope additionality is taking place in case the coverage of an activity is expanded to a wider range of markets, applications or players. Acceleration additionality is in place if participation in a specific scheme speeds up the course of the project. Finally, cognitive capacity additionality is defined as the positive impact on competencies, expertise and networks [29]. Only recently, researchers began to study this 
type of additionality. In doing so, they have mainly focused on behavioural additionality generated by traditional, direct $R \& D$ subsidies. Identified studies within this stream of research are studies by Hyvarinen and Rautiainen [37], Clarysse et al. [17], Hsu et al. [15], Wanzenboeck et al. [38] and Chavez and Sergio [39] studying behavioural additionality of R\&D grants in respectively Finland, Belgium, Taiwan, Austria and Spain. Our research specifically focuses on the extent to which indirect government mechanisms - in this case; technology intermediaries - could affect behavioural additionality at firm level. We hereby focus on cognitive capacity additionality. This research focus is mainly inspired by the importance of access to knowledge, technology and networks for many firms [7,9] and the market failure related to the transfer and exchange of information and knowledge [8]. Cognitive capacity additionality may occur if new partnerships are built and if collaboration and networking involve both individual and organizational learning, thereby increasing the competences of the actors [30]. Cognitive capacity additionality therefore refers to two types of additionalities: network and competence additionality. These sub-dimensions are relevant, intermediate, outputs to firms in the innovation process. They relate to the concept of external search depth and breadth, as introduced by Laursen and Salter [40] who define search depth as the extent to which firms draw from the different sources or search channels in the innovation process; and search breadth as the number of external sources or search channels that firms rely upon in their innovation activities. As such, search depth is linked to the concept of competence additionality in our context, which explores the extent to which a firm strengthens its knowledge base through collaboration with, and enabled by, a specific external source, namely the technology intermediary. Search breadth is further linked to the concept of network additionality, which explores the extent to which a firm extends its network of sources external to the innovation process.

\section{Theory and conceptual framework}


In what follows, we develop our theoretical framework, in which we study the impact of firm and technology intermediary characteristics, and the intensity of interaction between both organizations on competence and network additionality.

\subsection{Absorptive capacity at firm level}

When firms lack sufficient internal R\&D resources, they will be more dependent on interorganizational collaborations [41]. Further, SMEs are less R\&D focused, and more reliant on their external environment, when undertaking innovation activity compared to larger firms [42-43]. If firms are to acquire new knowledge, they must know where and how to find it, and how to assimilate and diffuse it within the organization. Cohen and Levinthal [44] argue that the ability of a firm to recognize the value of new, external information, assimilate it, and apply it to commercial ends is critical to its innovative capacity. They argue that the ability to evaluate and use external knowledge will to a large extent be determined by the availability of prior related knowledge. These abilities have been labelled "absorptive capacity" and are derived from the cognitive structures that underlie learning [44]. Similarly, Zahra and George [45] define absorptive capacity as a set of organizational routines and processes by which firms acquire, assimilate, transform, and exploit knowledge to produce a dynamic organizational capability. Through these capabilities, the firm can reconfigure its resource base and adapt to changing market conditions in order to achieve competitive advantage.

At firm level, absorptive capacity can be generated in a variety of ways: through $\mathrm{R} \& \mathrm{D}$ investment, as a byproduct of a firm's manufacturing operations, or by sending personnel for advanced technical training [44]. In their study on organizational learning, Lane and Lubatkin [46] argue that understanding the relevant basic knowledge permits the 'student' firm to understand the assumptions that shape the 'teacher' firm's knowledge and to be in a better position to evaluate the importance of the transferred knowledge. Similarly, Wong and He [47] mention that a firm's internal climate for innovation functions as a moderator for the 
relationship between R\&D support and firm innovation behaviour. Muscio [42] further indicates that firms learn from a variety of external sources [48] and must master the capabilities required to search, find, access and interpret information embodied in external organizations, in order to successfully access new knowledge through collaborations. Therefore, if a firm is to benefit from assistance of, or interaction with, a technology intermediary, it will have to possess sufficient absorptive capacity. As such, we follow Huang and $\mathrm{Yu}$ [49]'s assertions that firms with more absorptive capacity will be able to utilize external knowledge obtained from R\&D collaborations in a better way. Or, as Laursen and Salter [40] state: "firms with high levels of R\&D intensity are better able to exploit a host of search channels in terms of breadth and depth". We therefore expect firms with higher levels of absorptive capacity to be better enabled to engage in search depth, or to draw deeply from the external resources offered by, or through, the technology intermediary. As such, the firm will have to possess sufficient absorptive capacity in order to evaluate the importance of new knowledge offered through the technology intermediary and to integrate it in its innovation activities, or; to generate competence additionality.

This leads to the following hypothesis:

H1a: There is a positive relationship between firm absorptive capacity and competence additionality generated through firm-technology intermediary interaction

Absorptive capacity will, however, not only be required to generate competence additionality, or to enhance the firm's search depth. In line with Laursen and Salter [40] we argue that absorptive capacity will also enable the exploitation of search channels in terms of breadth. Indeed, a firm's strong absorptive capacity further increases its capabilities in building linkages between new knowledge and its existing knowledge and it lowers the levels of challenge related to the duplication of knowledge by partners they collaborate with [50]. Finally, higher levels of absorptive capacity will enable firms to understand and detect knowledge available with different parties in the environment, and to assess the potential 
value of networking possibilities. As such, when technology intermediaries engage in their task of network enhancement between organizations, their efforts may have higher impact with firms that have sufficient absorptive capacity to understand and detect relevant knowledge through networking. We therefore expect firms with higher levels of absorptive capacity to be better enabled to engage in search breadth, or to draw from many external resources offered by or through the technology intermediary, or; to generate network additionality.

This leads to the following hypothesis:

\section{H1b: There is a positive relationship between firm absorptive capacity and network additionality generated through firm-technology intermediary interaction}

\subsection{Absorptive capacity at technology intermediary level}

Further, we argue that technology intermediaries will also require absorptive capacity to evaluate the relevance and importance of external information and to play a role in technology intermediation. If this is the case, not only the need for absorptive capacity by the "clients" of the technology intermediaries will affect the impact of technology intermediary activities, but so will the need to build absorptive capacity in-house at the technology intermediary. Or, as Lane and Lubatkin [46] argue, the ability of a firm to learn from another firm is jointly determined by both student and teacher firm characteristics. Along the same lines, Acs et al. [51] and Lazaric et al. [52] indicate that both recipient and emitter of knowledge have to possess sufficient absorptive capacity in order for successful knowledge exchange to take place. Furthermore, the importance of absorptive capacity at both recipient and emitter level has been emphasized in other contexts. For instance, Lane et al. [53] studied international joint ventures and found that both the joint ventures and their foreign parents need similar knowledge bases for optimal collaboration. By consequence, not only absorptive capacity at member firm level, but also absorptive capacity at technology intermediary level will positively affect competence additionality. 
This leads to the following hypothesis:

H2a: There is a positive relationship between the technology intermediary's absorptive capacity and the firm's competence additionality generated through firm-technology intermediary interaction

To generate network additionality at firm level, the technology intermediary will also need sufficient absorptive capacity. Indeed, technology intermediaries will have to screen the market in order to assess which knowledge could be relevant and in order to assess which external linkages could be relevant to which type of firm. Following Laursen and Salter [40]'s argumentation that absorptive capacity will also enable the exploitation of search channels in terms of breadth, we expect firms to benefit from the technology intermediary's absorptive capacity, resulting in better search breadth. When a technology intermediary has better search capabilities, and the absorptive capacity to understand and capture external knowledge, it will be better positioned to bring together relevant parties, and to enhance network additionality.

This leads to the following hypothesis:

H2b: There is a positive relationship between the technology intermediary's absorptive capacity and the firm's network additionality generated through firm-technology intermediary interaction

\subsection{Firm-technology intermediary interaction}

While both firm and technology intermediary absorptive capacity will matter, it will be insufficient to merely expose the recipient to the relevant knowledge. Cohen and Levinthal [44] indicate that, in order for learning effects to take place, intensity of effort is crucial. Other authors [54-55] agree that continuous and frequent interactions are a precondition for successful innovation collaborations. Similarly, Falk [30] argues that variables to capture behaviour would have to be regressed on the incidence or even the size of public assistance. 
Bennett and Robson [56] found similar indications on the importance of intensity of contact in another context. Studying suppliers and clients of business services, they found that the higher the interaction intensity in service delivery, the better the outputs are evaluated by SME clients. They contribute this to information asymmetries between buyer and seller, which can be decreased through intense interaction. Finally, Laursen and Salter [40] argue that organizations have to go through a period of trial and error to learn how to gain knowledge from an external source. They will have to dedicate extensive effort which they will have to sustain over time, in order to build a shared understanding and common ways of working together. Therefore, in firm-technology intermediary collaboration, not only will it be important to expose the member firm to knowledge and services through the technology intermediary, but so will the intensity of the interaction between both.

This leads to the following hypothesis:

H3a: There is a positive relationship between intensity of firm-technology intermediary interaction and competence additionality generated by the firm

Finally, the intensity of interaction will also be crucial in generating network additionality. It is well acknowledged that intensity of interaction is important in network formation. Specifically, intensity of interaction facilitates the transfer of tacit knowledge, establishes conditions for relational and structural embeddedness and provides cost efficiency [57]. Further, Autio et al. [1] argue that the frequency of interaction among the members of a community is one of the most important mechanisms for the formation of community identification [58-59]. Community identification develops gradually through recurring informal exchanges [60-61]. Through repeated interaction, community members develop shared subcultures, which facilitate further identification among community members [1]. Autio et al. [1] found full and partial mediation effects for the strengthening of interaction frequency and community identification on direct technological learning. Therefore, intensity 
of interaction between member firm and technology intermediary is likely to positively affect network additionality generated by the firm.

This leads to the following hypothesis:

H3b: There is a positive relationship between intensity of firm-technology intermediary interaction and network additionality generated by the firm

Figure 1 summarizes our conceptual framework.

$<<<$ Insert Figure 1 about here $>>$

\section{Methodology}

\subsection{The sample and data collection}

To assess the impact of firms' interaction with technology intermediaries on cognitive capacity additionality, we study the so-called "collective research centres" (CRCs) in Belgium. In the aftermath of the Second World War, policy makers wanted to encourage scientific and technological research in specific sectors of the economy to improve productivity, quality and production. Because of budgetary constraints, the law of 1947 provided the possibility that firms within a sector could create a technology intermediary the collective research centres - based on mandatory membership of incumbent firms. The juridical form of the technology intermediate is a private non-profit organisation, partly financed by the collection of member fees (a small percentage of their sales); the sale of support services rendered towards members and non-members; the funding of particular services by governments (e.g. patent cells); and the participation in public research (e.g. EU Framework Programs). Hence, CRCs typically receive over 50\% of their financial means from public sources. These centres have, therefore, a large degree of autonomy even though 
their research agendas are partly shaped by a 'permanent' or 'technical committee' in which several (usually large) firms are present. This mode of organization ensures that research is partially initiated in a bottom-up fashion, ensuring the relevance of the research activities for the entire sector [62]. Collective research centres, just as other TIs, engage in need detection of firms. In the case of the collective research centres this occurs through specialized interaction modes. Technical advisors visit firms to study the possibilities of ameliorating the production process. This activity is subsidized by governments, because the need for knowledge spillovers is particularly felt in low tech sectors. Hence, a large part of the activities of technology intermediaries rest for a significant part on personal contacts.

The twelve collective research centres under study cover industrial sectors such as wood (to which, in 2006, the furniture industry was added); ceramics; machinery (expanded in the course of time with twelve other sectors into the 'technological' industry); roads; construction; cement; textile, diamond, coatings and paintings, metallurgy, welding, and packaging. The centres represent about 80,000 members. In a first stage, information is collected on the collective research centres' activities and their resource base through face-toface interviews. Following the Frascati manual [63], these activities are split up in research \& development (R\&D) and $R \& D$ related activities that deal with technology diffusion (e.g. information services, testing, technical accountancy, advice). Other activities (such as administration, marketing, reception, etc.) that are mainly internal to the Collective Research Centre (CRC) are not taken into account. The first stage of our datacollection resulted in a list of $R \& D$ and $R \& D$ related activities that firms call upon and that are used in the second stage. In this stage, we asked the CRC's member firms to respond to an online questionnaire on their engagement in activities with the CRCs. The questionnaire presents an overview of the activities, generated in the first phase of the project, and asks respondents to indicate whether or not they have called upon specific activities over the previous three years. An overview of the activities and the extent to which the firms called upon these over the past three years is included in Table 1. If the firm had used one of the CRC's services over the past three years, the firm is asked to answer a number of questions on cognitive capacity additionality. 
Additional information at firm level was also collected, including age and data on absorptive capacity. This information is complemented by annual accounting information retrieved from a business repertory, Belfirst.

$<<<$ Insert Table 1 about here $>>$

The data collection process was initiated by the CRCs, which selected randomly about $11 \%$ of their firm population and requested them to fill out the online questionnaire. The respondents could answer the questionnaire either in French or Dutch. 856 answers were received, resulting in a response rate of $9.4 \%$. The fact that the CRCs contacted respondents could potentially have generated a selection bias. An analysis of the answers received did not suggest such selection bias. First, the R\&D intensities of the respondents are in line with sector averages. The expected average of R\&D intensities, based on official statistics [64] (weighted by the number of respondents per sector) is $1.9 \%$ of sales, whereas the weighted reported average of $\mathrm{R} \& \mathrm{D}$ intensities is $2.4 \%$, which indicates a minor discrepancy. Further, the size distribution of the respondents is similar to the size distribution of the total population. Further, 214 respondents indicate not to have been in contact with any of the CRCs over the past three years indicating that the CRCs did not select their "most satisfied customers". After deleting observations with missing values, the database contains 115 valid answers from firms which have worked with the CRCs for R\&D activities over the past three years, and 289 valid answers from firms that have collaborated with the CRCs for R\&D related activities.

\subsection{Measures}

\subsubsection{Dependent variables}

Following Falk [30] we directly asked the assisted firms to assess cognitive capacity obtained through working with the technology intermediaries. For both R\&D related and R\&D activities, we assessed network and competence additionality. The source of items was 
a study $[17,65]$ in which the scales were tested and validated. In case the firm indicated that it had used the technology intermediary's service over the past three years, it received a list of items on cognitive capacity additionality related to the service, and was asked to indicate on a 7-point Likert scale the extent of agreement with a number of statements $(1=$ disagree entirely; $7=$ agree entirely). Table 2 provides an overview of items used and Cronbach Alpha's of the summated measures.

$<<<$ Insert Table 2 about here $>>$

Subsequently, summated scales were calculated for network and competence additionality (which are the two sub-dimensions that constitute cognitive capacity additionality) by calculating the average scores. Given that we received responses for both firms engaging in $R \& D$ activities and $R \& D$ related activities, and assessed for each of these the network and competence additionalities, we have four dependent variables that will be used throughout the analysis.

\subsubsection{Independent variables}

Absorptive capacity of the member firm. Cohen and Levinthal [44] argued that the ability to exploit external knowledge is largely influenced by the level of prior knowledge, which they refer to as "absorptive capacity". According to Muscio [42], R\&D efforts are a viable proxy for absorptive capacity. Subsequently, absorptive capacity of the member firm was measured as a categorical variable, indicating $R \& D$ expenses as a percentage of sales $(1=$ no $R \& D$ expenses; $2=R \& D$ expenses account for less than $5 \%$ of revenues; $3=R \& D$ expenses account for between 5 and $10 \%$ of revenues; $4=\mathrm{R} \& \mathrm{D}$ expenses account for more than $10 \%$ of revenues).

Absorptive capacity of the TI. Absorptive capacity of the TI (technology intermediary) is measured as the R\&D personnel in full time equivalents (FTEs). As most R\&D expenses of 
TIs go to R\&D personnel costs (71\%), this is a sufficient proxy for R\&D intensity. Especially since it is the $R \& D$ personnel which detects firm needs, screen the environment for external knowledge, and assist firms with technical advice.

Intensity of interaction. For each of the services in Table 1, we asked to indicate the extent to which the member firm used the service, using a 7 point-Likert scale (for question and scale, see Table 1). We use a summated scale of the engagement in $R \& D$ related activities by taking the average of the engagement in each of the R\&D related activities. Cronbach Alpha for the scale was .93 . We construct a summated scale of the engagement in R\&D activities by taking the average over the two R\&D items (Table 1). Cronbach Alpha for the scale was .80 .

\subsubsection{Control variables}

Slack. George [66] argues that slack may affect the behaviour of firms, in turn affecting financial performance. For instance, studies have indicated that slack is a predictor for risk taking [67], innovation [68] and performance [69-70]. Slack is used to stabilize a firm's operations by absorbing excess resources during periods of growth and by allowing firms to maintain their aspirations and internal commitments during periods of distress [66,71]. We control for slack given the impact it may have on firm behaviour. Following George [66], we measured slack as the ratio cash flow of the firm/average cash flow in the sector, taking into account that slack may be industry specific.

Age. We control for age, given that age is an important moderator of the effectiveness with which firms deploy resources [66,72-73] and may therefore affect the extent to which working with the technology intermediary generates cognitive capacity additionality.

Sector $R \& D$ intensity. We control for the sector by adding the sector R\&D intensity, as provided by the Belgian Science Policy Office [64] for the year 2006. We prefer incorporating sector R\&D intensity over sector dummies, given that the extent to which firms 
can additionally benefit from collaboration with technology intermediaries may depend upon the extent to which the sector in which the firm operates engages in $R \& D$. The $R \& D$ intensity is measured as the $R \& D$ expenses divided by the total value added of a sector.

\section{Results}

In what follows, we first present the results of the analysis for $R \& D$ activities, followed by the analysis for R\&D related activities, including diffusion of technology. As such, we follow Cohen and Levinthal [44] and the Frascati manual [63] which recommends distinguishing between $R \& D$ and $R \& D$ related activities. For each type of activities, we present the descriptive statistics for the variables used.

\subsection{Cognitive capacity additionality generated through $R \& D$ activities}

Table 3 provides the descriptive information for the variables used. Engaging in R\&D activities with the CRCs resulted, for the average firm, in network additionality of 4.34 and competence additionality of 4.78 . The average technology intermediary engaged 70 people in $\mathrm{R} \& \mathrm{D}$, which is representing the absorptive capacity of the technology intermediary. Firms responding are on average 29 years old and have on average 12,492 Euro of slack. The average sector $\mathrm{R} \& \mathrm{D}$ intensity is $2.72 \%$.

$<<<$ Insert Table 3 about here $>>>$

We use ordinary least squares (OLS) regression analysis with both competence and network additionality for $R \& D$ activities as dependent variables.

Correlations between variables are all below 0.2. In order to make sure that multicollinearity was not an issue, variance inflation factors are calculated, and are found to be below 3.0 (maximum value 1.2), suggesting that multicollinearity is not an issue (see Hair et al. [74]). 
The first iteration of the regression analysis for cognitive capacity additionality of $\mathrm{R} \& \mathrm{D}$ activities does not provide support for hypotheses $1 \mathrm{a} \& \mathrm{~b}$ nor $2 \mathrm{a} \& \mathrm{~b}$. The analysis supports hypotheses $3 \mathrm{a} \& \mathrm{~b}$, indicating that a higher intensity of use of the technology intermediary services by the firm affects network and competence additionality positively (see left hand side of Table 4). Further analysis however indicated that the relationship between the absorptive capacity (AC) of the firm and cognitive capacity additionality may be mediated by the intensity of interaction (right hand columns of Table 4). Indeed, when leaving the intensity of interaction out of the analysis, the absorptive capacity of the firm was found to positively affect both network and competence additionality.

In order to test for full and partial mediation effects, we first follow the approach suggested by Baron and Kenny [75]. According to Baron and Kenny [75], full mediation occurs when the following four conditions are met: (1) independent variables must affect the mediator. The impact of the firm's absorptive capacity on intensity of interaction was statistically significant (model significant at $\mathrm{p}<0.01$; beta $=0.52 ; \mathrm{p}<0.01$ ); (2) the independent variables must affect the dependent variable; (3) the mediator must affect the dependent variable; (4) the independent variable is not significant in the full model. All conditions were fulfilled in the case of absorptive capacity of the firm, indicating that intensity of interaction fully mediates the relationship between absorptive capacity of the member firm and network and competence additionality. Given recent critique on the approach developed by Baron and Kenny (for an overview, see Preacher and Hayes [76-77], we test the robustness of our results by using a Sobel test with bootstrap procedures $(5,000$ bootstrap samples). The estimate of the indirect effect of absorptive capacity of the member firm on competence additionality, via intensity of interaction is 0.24 . This effect is statistically significant $(\mathrm{p}<0.01)$. Furthermore, the bootstrapped estimate of the indirect effect lies between 0.07 and 0.42 , with $95 \%$ confidence. We conclude that the indirect effect is significantly different from zero at $p<0.05$ (two tailed).The estimate of the indirect effect of absorptive capacity of the member firm on 
network additionality, via intensity of interaction is 0.14 . This effect is statistically significant ( $\mathrm{p}<0.05)$. Furthermore, the bootstrapped estimate of the indirect effect lies between 0.03 and 0.26, with 95\% confidence. Again, we conclude that the indirect effect is indeed significantly different from zero at $\mathrm{p}<.05$ (two tailed).

Figure 2 illustrates the relationship between independent and dependent variables for R\&D activities.

<<<Insert Figure 2 about here >>

The model indicates that, the higher the absorptive capacity of the firm, the higher the engagement of the firm in $R \& D$ activities with the technology intermediary, resulting, in turn, in higher levels of cognitive capacity additionality. Results were similar for both network and competence additionalities. In what follows, we test our hypotheses for R\&D related activities, using similar analysis techniques. The results are also visualized in Figure 2.

\subsection{Cognitive capacity additionality generated through $R \& D$ related activities}

Table 5 provides an insight into the descriptive statistics for both dependent and independent variables. The average firm tends to generate more competence additionality (average of 5.16) than network additionality (average of 3.66) from R\&D related activities.

$$
<<<\text { Insert Table } 5 \text { about here }>>>
$$

We use ordinary least squares (OLS) regression analysis with network and competence additionality for $\mathrm{R} \& \mathrm{D}$ related activities as dependent variables. Correlations between variables were all below 0.25 . Variance inflation factors (VIF) are calculated, and all below 3.0 (maximum value 1.1), suggesting that multicollinearity issues do not occur (see Hair et al [70]). 
The results do not provide support for hypothesis $1 \mathrm{a} \& \mathrm{~b}$ and $2 \mathrm{~b}$, and do provide support for hypotheses $2 \mathrm{a}, 3 \mathrm{a} \& \mathrm{~b}$ : the intensity of interaction between technology intermediary and firm and the absorptive capacity at technology intermediary level positively affect competence additionality generated by the firm. Furthermore, absorptive capacity by the firm does not show to have any positive effects on network or competence additionality, with similar results for both network and competence additionality. Interestingly, the effect for absorptive capacity of the technology intermediary was even in the opposite direction than expected for network additionality: a higher level of absorptive capacity by the technology intermediary negatively affects network additionality. Again, we test for mediation effects. To test for these effects, we run the regression analyses again, without "intensity of interaction" in the equation. These results are reported in the right hand side of Table 6.

\section{$<<<$ Insert Table 6 about here $>>$}

In the case of network and competence additionality, the absorptive capacity of the firm had a significantly positive effect, but the effect disappeared after including the intensity of interaction in the equation, pointing to a full mediation effect. Here again, after finding the mediating effect using the Baron and Kenny [75] approach, we use the Sobel test with bootstrap procedures (5,000 bootstrap samples). The estimate of the indirect effect of absorptive capacity of the firm on competence additionality, via intensity of interaction is 0.12 . This effect is statistically significant $(\mathrm{p}<0.01)$. Furthermore, the bootstrapped estimate of the indirect effect lies between 0.03 and 0.21 (with 95\% confidence), again leading to the conclusion that the indirect effect is significantly different from zero at $\mathrm{p}<0.05$ (two tailed). The estimate of the indirect effect of absorptive capacity of the member firm on network additionality, via intensity of interaction is 0.10 . This effect is statistically significant $(\mathrm{p}<0.05)$. Furthermore, the bootstrapped estimate of the indirect effect lies between 0.02 and 0.20 , with 95\% confidence. We therefore conclude that the indirect effect is indeed significantly different from zero at $\mathrm{p}<0.05$ (two tailed). 
The results indicate that higher levels of absorptive capacity of the firm result in an increased engagement in technology intermediary $R \& D$ related activities, and results, through the mechanism of intensity of interaction, in higher network and competence additionality. Interestingly, the absorptive capacity of the technology intermediary negatively affected network additionality. We discuss these findings in the next section.

\section{Conclusions and discussion}

Governments are increasingly turning towards the use of indirect mechanisms to stimulate firm $R \& D$ investment. This can, amongst others, be explained by the increased awareness of the existence of market failure related to the transfer and flows of information between several parties in an innovation system. Little evidence, however, exists on the impact of initiatives aimed at stimulating interaction and technology and knowledge diffusion, such as the creation or financing of technology intermediaries. One of these initiatives are the collective research centres which were set up in Belgium in order to speed up technological innovation and renewal. These initiatives, supported by government, may affect firms in different ways. Previous research [30] has labelled these different types of effects input, output and behavioural additionality. Our research specifically focussed on one dimension of behavioural additionality, namely cognitive capacity additionality. We studied network and competence additionality for $R \& D$ and $R \& D$ related activities carried out in relation with the technology intermediaries. Building on the concepts of absorptive capacity, we anticipated that the absorptive capacity of the technology intermediary and the firm, and the intensity of interaction of the technology intermediary with the firm would positively affect cognitive capacity additionality. We found that, both for R\&D and R\&D related activities, cognitive capacity additionality is positively affected by the intensity of use of the services offered by the technology intermediary, pointing to a significant learning effect. We also found that interaction with TIs is mediating the effect of absorptive capacity at firm level and cognitive capacity additionality, with more $R \& D$ intensive firms calling more frequently upon the 
technology intermediary's services. We did not find absorptive capacity of the technology intermediary to positively affect the cognitive capacity additionality generated by the firms, and even found a negative impact for the impact of absorptive capacity of the CRC on cognitive capacity additionality of the member firm in case of $R \& D$ related activities. This might be attributed to the fact that TIs have a dominant impact on firms active in low tech sectors, preventing firms to develop internal networking capabilities.

Overall, the results show that especially those companies that have sufficient absorptive capacity to engage in $R \& D$ and innovation activities benefit from working with the technology intermediary. This effect mainly occurs through the intensity of the involvement in CRC activities. When we discussed this conclusion with the collective research centre representatives, they pointed to the fact that over the past years, they had worked less intensively with smaller and especially lower $R \& D$ intensive member firms. The reason for lower collaboration with low $\mathrm{R} \& \mathrm{D}$ and smaller firms lies, according to the representatives of the CRCs, in the fact that government has urged them to alter their ambitions at innovation and technology level, and to work towards technological breakthroughs that would also provide more visibility to the work of the technology intermediary and the government investment. This has led to less investment by the CRCs in awareness creation with small and low $R \& D$ intensive companies and to increased interest in larger projects, carried out with companies that have already established an R\&D department. This indicates that working with technology intermediaries is relevant to firms that already possess absorptive capacity, and that, if awareness creation for technology or innovation is the main goal, governments should reward or finance technology intermediaries based on their involvement in awareness creation.

Another interesting finding was that higher levels of absorptive capacity at technology intermediary level resulted in lower network additionality from R\&D related activities. However, the interviews with the CRCs indicated that they find their personal engagement in $R \& D$ crucial as without having in-house $R \& D$ personnel, they do not believe 
to have the absorptive capacity needed to provide relevant services to firms (which is illustrated by the positive impact of their absorptive capacity on competence additionality for $R \& D$ related activities). For instance, for $R \& D$ activities, they indicated that they would never be able to define relevant research topics and disseminate the results to firms without following up on technological evolution and trends by engaging in R\&D themselves. The results, however, do not indicate that CRC R\&D capacity affects network additionality positively. These results may suggest that CRCs are not seen as providers of networking opportunities, but could instead be seen as vehicles that replace the firm's own networking activities. As such, the more absorptive capacity the CRC has, the more it is seen as a potential substitute for the firm's own networking activities. In this way, the CRC would play a gatekeeping role on behalf of the firm, with the firm expecting the CRC to maintain its relationships, which would not have been captured with the questions on cognitive capacity additionality, since these questions aim at studying the complementary role of the CRC compared to the member firm's activities. Further research could purposefully assess the extent to which technology intermediaries are seen as substitutes for the firm's own activities.

This research leads to a number of directions for further research. First, it is clear that network and competence additionality are intermediate outputs, which should subsequently result in output additionality, related to the generation of innovation, financial and marketrelated outputs. Further research could purposefully assess the extent to which cognitive capacity additionality translates in output additionality using a longitudinal research design. Second, other theoretical frameworks could successfully be applied to study behavioural additionality generated through technology intermediaries. Indeed, other factors, such as cognitive distance between technology intermediary and firm could affect this behavioural outcome. Future research could analyse to which extent such factors are likely to shape behavioural outcomes.

This research has a number of implications for industry, policy makers and academics. For industry, this research points to the importance of building absorptive capacity within the firm to benefit from working with other parties in the innovation system. It further shows that 
it is insufficient for firms to rely on external parties, such as technology intermediaries, without engaging internally in network and competence building. Further, it indicates that, in order for higher levels of cognitive capacity additionality to be generated, intensity of interaction is crucial in firm-technology intermediary interactions.

For policy makers, this paper has three main findings. First, this paper indicates that, apart from potential input or output additionality generated through working with technology intermediaries, firms also benefit from working with them, through increasing networking and cognitive capabilities, which constitutes one of the indications of the effectiveness of government money spent. Second, the results also indicate that companies may be relying too much on technology intermediaries, and may expect technology intermediaries to take over some of their roles. Engaging in networks on behalf of the firm is one example. And third, the results show that technology intermediaries may be less effective in encouraging companies, especially smaller ones, to engage in $R \& D$ and innovation activities, especially when the government program supporting the technology intermediary is focussing on breakthrough technological developments. The results show that especially those companies that have already built absorptive capacity internally engage in activities with the technology intermediary and generate higher levels of cognitive capacity additionality.

In sum, we show that it is beneficial for policy makers to focus on providing help to SMEs through technology intermediaries, but that other types of networking support should complement the technology intermediary's function. This could, for instance, be accomplished by integrating SMEs as partners in Framework programmes, in which they are stimulated to interact with other parties, without relying on other actors, such as technology intermediaries, to take over this interaction role.

For academics, this research indicates that it is important for research building on absorptive capacity to incorporate potential mediation effects. Whereas many researchers have assumed a direct relationship between learning and different types of outcome, this research shows that indirect effects may be important to disentangle the relationship between learning and outcome. It further complements previous research on learning, indicating that 
absorptive capacity at both teacher and student level will be important in order for learning effects to occur. Our research shows that, under certain conditions, in which the student relies too heavily on the teacher, the teacher's absorptive capacity may negatively affect learning outcomes. Further, this research was one of the first to study the impact of technology intermediaries and, in general, indirect policy measures, on the learning and networking outcomes of their users. As such, we have contributed to organizational learning theory by assessing the generalizability of the theory in the context of firm-technology intermediary interactions. Our results indicate that an organizational learning framework holds empirical validity in this context, even though refinement is needed, particularly at the level of absorptive capacity at technology intermediary or "teacher" level. Finally, our results add to the understanding of the impact of firms' search strategies through one specific type of channel, namely technology intermediaries, and as such respond to a call for further research by Laursen and Salter [40] to further explore their results on search breadth and depth through specific channels. 


\section{References}

[1] Autio, E., Kanninen, S., Gustafsson, R., 2008. First-and second-order additionality and learning outcomes in collaborative R\&D programs. Research Policy 37, 59-76.

[2] Luukkonen, T., 2000. Additionality of EU framework programmes. Research Policy 29(6), 711-725.

[3] Nelson, R., 1959. The simple economics of basic scientific research. Journal of Political Economy 67, 148-163.

[4] Dasgupta, P., David, P., 1994. Toward a new economics of science. Research Policy 23, 487-521.

[5] Arrow, K., 1962. Economic Welfare and the Allocation of Resources for Invention in Nelson R. (ed). The rate and direction of inventive activity. Princeton, NJ, Prinecton University Press, 609-626.

[6] Dalziel, M., 2010. Why do innovation intermediaries exist? Paper presented at the 2010 Druid conference, 16-18 August, Imperial College Business School, London.

[7] Dodgson, M., Rothwell, R., 1994. The Handbook of Industrial Innovation. Cheltenham: Edward Elgar.

[8] Nooteboom, B., 1994. Innovation and diffusion in small firms: Theory and Evidence. Small Business Economics 6, 327-347.

[9] Von Hippel, E., 1988. The Sources of Innovation. New York: Oxford University Press.

[10] Mowery, D., 1994. Science and Technology Policy and Interdependent Economies. Kluwer Academic Publishers, Boston .

[11] Cantner, U., Pyka, A., 2001. Classifying technology policy from an evolutionary perspective. Research Policy 30, 759-775.

[12] Malerba, F., 1997. Technological regimes and sectoral patterns of innovative activities. Industrial and Corporate Change 6(1): 83-118. 
[13] Park, Y-T., 1999. Technology diffusion policy: a review and classification of policy practices. Technology in Society 21, 275-286.

[14] David, P., Hall, B., Toole, A., 2000. Is public R\&D a complement or substitute for private R\&D? A review of econometric evidence. Research Policy 29(4/5), 497-529.

[15] Hsu, F-M., Horng, D-J., Hsueh, C-C., 2009. The effect of government-sponsored R\&D programmes on additionality in recipient firms in Taiwan. Technovation 29(3), 204-217.

[16] Koga, T., 2005. R\&D subsidy and self-financed R\&D: The case of Japanese hightechnology start-ups. Small Business Economics 24(1), 53-62.

[17] Clarysse, B., Wright, M., Mustar, P., 2009. Behavioural additionality of R\&D subsidies: a learning perspective. Research Policy 38(10), 1517-1533.

[18] Hall, B., Van Reenen, J., 2000. How effective are fiscal incentives for R\&D? A review of the evidence. Research Policy 29(4/5), 449-469.

[19] Lee C-Y., 2011. The differential effects of public R\&D support on firm R\&D: theory and evidence from multi-country data. Technovation 31(5/6), 256-269.

[20] Nishimura, J., Okamuro, H., 2011. Subsidy and networking: the effects of direct and indirect support programs of the cluster policy. Research Policy 40(5), 714-727.

[21] Davenport, S., Grimes, C., Davies, J., 1998. Research collaboration and Behavioural Additionality : A New Zealand Case Study. Technology Analysis and Strategic Management 10(1), 55-67.

[22] Howells, J. 2006. Intermediation and the role of intermediaries in innovation. Research Policy 35(5), 715-729.

[23] Malerba, F., 2002. Sectoral systems of innovation and production. Research Policy 31 (2), 247-264.

[24] Sapsed, J., Grantham, A., DeFillippi R., 2007. A bridge over troubled waters: bridging organizations and entrepreneurial opportunities in emerging sectors. Research Policy 36(9), 1314-1334.

[25] Bessant, J., Rush, H., 1995. Building bridges for innovation: the role of consultants in technology transfer. Research Policy 24(1), 97-114. 
[26] Kyonghwan K., Yongrok C., Chang Y., Hye J. 2010. The role of intermediaries on technological risk management and business development performance in Korea. Technological Forecasting and Social Change. 77(6), 870-880.

[27] Chesbrough, H., 2003. The era of open innovation, MIT Sloan Management Review 44 (3), 35-41.

[28] Spithoven, A., Clarysse, B., Knockaert, M., 2010. Building absorptive capacity to organize inbound open innovation in traditional industries. Technovation 30(2), 130-141.

[29] Alexander A., Martin D. 2013. Intermediaries for open innovation: a competence-based comparison of knowledge transfer offices practices. Technological Forecasting and Social Change. 80(1), 38-49.

[30] Falk, R., 2007. Measuring the effects of public support schemes on firms' innovation activities. Survey evidence from Austria. Research Policy 36, 665-679.

[31] Bach, L., Matt, M., 2002. Rationale for science and technology policy. In: Georghiou L., Rigby J. (Eds). Assessing the socio-economic impacts of the Framework Programme. Report to European Commission DG Research.

[32] Metcalfe, J., Georghiou, L., 1997. Equilibrium and Evolutionary Foundations of Technology Policy. Paper presented at the OECD Workshop on "Best Practices and Approaches in Technology and Innovation Policy- New Rationale and Approaches in Technology and Innovation Policy", 30-31 May 1997, Vienna.

[33] Buisseret, T., Cameron, H., Georghiou, L., 1995. What difference does it make? Additionality in the public support of $R \& D$ in large firms. International Journal of Technology Management 10(4/5/6), 587-600.

[34] Hewitt-Dundas, N., Roper, S., 2010. Output additionality of public support for innovation: evidence for Irish manufacturing plants. European Planning Studies 18(1), 107122.

[35] Aerts, K., Schmidt, T., 2008. Two for the price of one? Additionality effects of R\&D subsidies: a comparison between Flanders and Germany. Research Policy 37(5), 806-822. 
[36] Georghiou, L., 1997. Issues in the evaluations of innovation and technology policy. In: Policy evaluation in innovation and technology: towards best practice, chapter 3, OECD, Paris.

[37] Hyvarinen, J., Rautiainen, A-M., 2007. Measuring additionality and systemic impacts of public research and development funding - the case of TEKES, Finland. Research Evaluation 16(3), 205-215.

[38] Wanzenboeck, I., Scherngell, T., Fischer, M., 2013. How do firm characteristics affect behavioural additionalities of public R\&D subsidies? Evidence for the Austrian transport sector. Techovation 33(2-3), 349-363.

[39] Chavez, A., Sergio, M., 2013. Behavioural additionality in the context of regional innovation policy in Spain. Innovation-Management policy and practice 13(1), 95-110.

[40] Laursen, K., Salter, A., 2006. Open for innovation: the role of openness in explaining innovation performance among UK manufacturing firms. Strategic Management Journal 27, $131-150$.

[41] Lin, B., 2003. Technology transfer as technological learning: a source of competitive advantage of firms with limited R\&D resources. R\&D Management 33(3), 327-341.

[42] Muscio, A., 2007. The impact of absorptive capacity on SMEs' collaboration. Econ. Innov. New. Techn. 16(8), 653-668.

[43] Waalkens, J., Jorna, R., Postma, T., 2004. Learning of SMEs in Networks: The Role of Absorptive Capacity. University of Groningen. Research Institute SOM, Research Report 04B14.

[44] Cohen, W., Levinthal, D., 1990. Absorptive Capacity: A New Perspective on Learning and Innovation. Administrative Science Quarterly 35, 128-152.

[45] Zahra, S., George, G., 2002. Absorptive capacity: a review, reconceptualization, and extension. Academy of Management Review 27(2), 185-203.

[46] Lane, P., Lubatkin, M., 1998. Relative absorptive capacity and interorganizational learning. Strategic Management Journal 19, 461-477. 
[47] Wong, P-K, He, Z-L., 2003. The moderating effect of a firm's internal climate for innovation on the impact of public R\&D support programmes. International Journal of Entrepreneurship and Innovation Management 3, 525-545.

[48] Malerba, F., 1992. Learning by firms and incremental technical change. The Economic Journal 102, 845-859.

[49] Huang, K-F., Yu C-M., 2011. The effect of competitive and non-competitive R\&D collaboration on firm innovation. Journal of Technology Transfer 36, 383-403.

[50] Zhang, J., Baden-Fuller, C. (2010). The influence of technological knowledge base and organizational structure on technology collaboration. Journal of Management Studies 47(4), 679-704.

[51] Acs, Z., Audretsch, D., Braunerhjelm, P., Carlsson, B., 2003. The missing link: the knowledge filter and endogenous growth. Working paper presented at the Druid Summer Conference on 'Creating, Sharing and Transferring Knowledge'. The Role of Geography, Institutions and Organization.' Frederiksberg, Denmark, 18-20 June 2003.

[52] Lazaric, N., Longhi, C., Thomas, C., 2008. Gatekeepers of knowledge versus platforms of knowledge: From potential to realized absorptive capacity. Regional Studies 42 (6), 837852.

[53] Lane, P., Salk, J., Lyles, M., 2001. Absorptive capacity, learning, and performance in international joint ventures, Strategic Management Journal 22, 1139-1161.

[54] Kirat, T., Lung, Y., 1999. Innovation and proximity- territories as loci of collective learning processes. European Urban and Regional Studies 6(1), 27-38.

[55] Asheim, B., Gertler, M., 2005. The Geography of Innovation: Regional Innovation Systems. In: Fagerberg, J., Mowery, D., Nelson, R. (eds). The Oxford Handbook of Innovation. Oxford University Press. Oxford. 291-317.

[56] Bennett, R., Robson, P., 1999. Intensity of interaction in supply of business advice and client impact: a comparison of consultancy, business associations and government support initiatives for SMEs. British Journal of Management 10, 351-369. 
[57] Williamson, O. (1985). The economic institutions of capitalism: firms, markets and relational contracting. New York: Free Press.

[58] Bouty, I., 2000. Interpersonal and interaction influences on informal resource exchanges between R\&D researchers across organizational boundaries. Academy of Management Journal 43(1), 50-65.

[59] Yli-Renko, H., Autio, E., Sapienza, H., 2001. Social capital, knowledge acquisition, and knowledge exploitation in young technology-based firms. Strategic Management Journal 22, 587-613.

[60] Granovetter, M., 1985. Economic action and social structure: the problem of embeddedness. American Journal of Sociology 91, 481-510.

[61] Ring, P., Van de Ven, A., 1994. Development processes of cooperative interorganizational relationships. Academy of Management Review 19, 90-108.

[62] Spithoven, A., Knockaert, M., Vereertbrugghen, C., 2009. Collective Research Centres: A Study on R\&D and Technology Transfer Involvement. Belspo Research Series 12.Brussels: Belgian Science Policy Office.

[63] OECD, 2002. Frascati Manual. Proposed Standard Practice for Surveys on Research and Experimental Development.

[64] Belgian Science Policy Office, 2011. www.belspo.be, accessed on 01.02.2011

[65] Steurs, G., Verbeek, A., Vermeulen, H. and Clarysse, B., 2006. What difference do IWT R\&D grants make for their clients? IWT Observatorium Brussels, accessed on $8^{\text {th }}$ September 2011: http://www.iwt.be/publicatie/48-making-difference-evaluation-behaviouraladditionality-rd-subsidies

[66] George, G., 2005. Slack resources and the performance of privately held firms. Academy of Management Journal 48(4), 661-676.

[67] Wiseman, R., Bromiley, P., 1996. Towards a model of risk in declining organisations: An empirical examination of risk, performance and decline. Organization Science 7, 524-543. [68] Nohria, N., Gulati, R., 1996. Is slack good or bad for innovation? Academy of Management Journal 39, 1245-1264. 
[69] Bromiley, P., 1991. Testing a causal model of corporate risk taking and performance. Academy of Management Journal 34, 37-59.

[70] Tan, J., Peng, M., 2003. Organizational slack and firm performance during economic translations: Two studies from an emerging economy. Strategic Management Journal 24, $1249-1264$

[71] Cyert, R., March, J., 1963. A behavioural theory of the firm. Englewood Cliffs. NJ: Prentice Hall.

[72] Stinchcombe, A., 1965. Social Structure and organizations. In: March J. (Ed.). Handbook of organizations: 142-193. Chicago: Rand McNally.

[73] Thompson, J., 1967. Organizations in action. New York: McGraw-Hill.

[74] Hair, J., Black, W., Babin, B., Anderson, R., Tatham, R., 1998. Multivariate data analysis. 5th ed. Prentice Hall: Upper Saddle River, N.Y.

[75] Baron, R, Kenny, D., 1986. The moderator-mediator variable distinction in social psychological research: conceptual, strategic, and statistical considerations. Journal of Personality and Social Psychology 51, 1173-1182.

[76] Preacher, K, Hayes, A., 2004. SPSS and SAS procedures for estimating indirect effects in simple mediation models. Behavior Research Methods, Instruments \& Computers 36(4), $717-731$.

[77] Preacher, K, Hayes, A., 2008. Asymptotic and resampling strategies for assessing and comparing indirect effects in simple and multiple mediator models. Behavior Research Methods, Instruments, and Computers 40, 879-891. 
Table 1: Overview of use made by the member firm of CRC services

\begin{tabular}{lcc}
\hline To which extent does your company call upon the following & Used over last 3 \\
CRC services? (1=never; 7 $=$ often) & & years? (\%)
\end{tabular}

$\underline{R \& D \text { related activities }}$

- R\&D laboratory for use of company

$\begin{array}{lll}2.73 & 1 & 38\end{array}$

- Information on R\&D European programmes

$2.16 \quad 1 \quad 24$

- Access to technical library

$3.66 \quad 3 \quad 56$

- Provision of qualified personnel

$2.91 \quad 38$

- Sales of equipment

$\begin{array}{lll}1.37 & 1 & 5\end{array}$

- Right to use inventions (licences)

$\begin{array}{lll}1.48 & 1 & 6\end{array}$

- Small scale in-depth technological consultancy (GTA)

$3.49 \quad 3 \quad 55$

- Support and advice concerning standardisation

$3.04 \quad 2 \quad 43$

- Information on intellectual property

$\begin{array}{lll}1.70 & 1 & 13\end{array}$

- Certification

$\begin{array}{lll}2.45 & 1 & 31\end{array}$

- Consulting and audits

$2.23 \quad 1 \quad 24$

- Testing

$\begin{array}{lll}3.28 & 2.5 & 46\end{array}$

- Feasibility studies

$\begin{array}{lll}1.95 & 1 & 17\end{array}$

- Provision of information through website

$3.56 \quad 3 \quad 54$

- Provision of information through publications

$3.66 \quad 3 \quad 55$

- Provision of information through newsletters

$\begin{array}{lll}3.80 & 4 & 63\end{array}$

- Norm antennas

$\begin{array}{lll}2.86 & 2 & 38\end{array}$

- European technology platform

$\begin{array}{lll}2.07 & 1 & 17\end{array}$

- Matching parties in industry and science

$\begin{array}{lll}2.27 & 1 & 27\end{array}$

- Organisation of studydays and seminars

$\begin{array}{lll}3.40 & 3 & 57\end{array}$

- Technology watch and roadmapping

- Solving specific problems (troubleshooting)

$\begin{array}{lll}1.89 & 1 & 18\end{array}$

- Technical advice

$3.03 \quad 2$

$\begin{array}{lll}4.09 & 4 & 68\end{array}$

\section{$\underline{\text { R\&D activities }}$}

- Research contract between CRC and company (bilateral) 2.04

- Research contract on a collective basis (CRC, your company and third parties)

$2.26 \quad 1 \quad 25$


Table 2: Overview of items used for assessing cognitive capacity additionality

\begin{tabular}{|c|c|c|}
\hline $\begin{array}{l}\text { Cognitive } \\
\text { capacity } \\
\text { additionality }\end{array}$ & $\mathrm{R} \& \mathrm{D}$ related activities & R\&D activities \\
\hline \multirow[t]{2}{*}{$\begin{array}{l}\text { Competence } \\
\text { additionality }\end{array}$} & $\begin{array}{l}\text { The intervention by the CRC allowed my } \\
\text { company to acquire new knowledge } \\
\text { The intervention by the CRC allowed my } \\
\text { company to increase its innovation management } \\
\text { capabilities } \\
\text { The intervention by the CRC allowed my } \\
\text { company to upgrade its human resources }\end{array}$ & $\begin{array}{l}\text { The project increased our skills to } \\
\text { network with universities or } \\
\text { public research centres } \\
\text { The project increased our skills to } \\
\text { network with other companies } \\
\text { The project allowed us to acquire } \\
\text { new knowledge } \\
\text { The project allowed us to upgrade } \\
\text { our human resources } \\
\text { The project increased our } \\
\text { innovation management } \\
\text { capabilities }\end{array}$ \\
\hline & Cronbach Alpha: .89 & Cronbach Alpha: .83 \\
\hline \multirow[t]{2}{*}{$\begin{array}{l}\text { Network } \\
\text { ditionality }\end{array}$} & $\begin{array}{l}\text { The intervention by the CRC allowed my } \\
\text { company to identify potential partners } \\
\text { The intervention by the CRC allowed my } \\
\text { company to cooperate with other companies } \\
\text { The intervention by the CRC allowed my } \\
\text { company to cooperate with knowledge } \\
\text { institutes, such as universities or research } \\
\text { institutes }\end{array}$ & $\begin{array}{l}\text { The project allowed us to } \\
\text { network with universities or } \\
\text { public research centres } \\
\text { The project allowed us to } \\
\text { network with other companies } \\
\text { The project allowed us to build } \\
\text { research networks }\end{array}$ \\
\hline & Cronbach Alpha: .89 & Cronbach Alpha: .90 \\
\hline
\end{tabular}

$\mathrm{N}=289$ for $\mathrm{R} \& \mathrm{D}$ related activities; $\mathrm{N}=115$ for $\mathrm{R} \& \mathrm{D}$ activities 
Table 3: Descriptives for R\&D activities

\begin{tabular}{rrrrr} 
Variable & Minimum & Maximum & Mean & S.d. \\
\hline Competence additionality & 1 & 7 & 4.78 & 1.07 \\
Network additionality & 1 & 7 & 4.34 & 1.57 \\
Absorptive capacity firm & & Categorical variable & \\
Absorptive Capacity TI & 8 & 133 & 70.07 & 48.13 \\
Intensity of interaction & 1 & 7 & 3.94 & 1.54 \\
Age (years) & 1 & 97 & 29.19 & 21.47 \\
Slack & $-4,250$ & 560,234 & 12,492 & 70,309 \\
Sector R\&D intensity & 0.48 & 7.57 & 2.72 & 2.69 \\
\hline
\end{tabular}

$\mathrm{N}=115$.

Table 4: OLS regression results for R\&D activities

Full Model

Mediation Test

\begin{tabular}{|c|c|c|c|c|}
\hline & $\begin{array}{l}\text { Competence } \\
\text { additionality }\end{array}$ & $\begin{array}{r}\text { Network } \\
\text { additionality }\end{array}$ & $\begin{array}{l}\text { Competence } \\
\text { additionality }\end{array}$ & $\begin{array}{r}\text { Network } \\
\text { additionality }\end{array}$ \\
\hline \multicolumn{5}{|l|}{ Independent variables } \\
\hline $\begin{array}{l}\text { Absorptive Capacity firm } \\
\qquad(\mathrm{H} 1 \& \mathrm{~b})\end{array}$ & .11 & .16 & $.21^{*}$ & $.28 * *$ \\
\hline $\begin{array}{r}\text { Absorptive Capacity TI } \\
\text { (H2a\&b) }\end{array}$ & -.13 & -.07 & $-.19^{\dagger}$ & -.16 \\
\hline $\begin{array}{l}\text { Intensity of interaction } \\
\qquad(\mathrm{H} 3 \mathrm{a} \& \mathrm{~b})\end{array}$ & $.31 * * *$ & $.40 * * *$ & & \\
\hline \multicolumn{5}{|l|}{ Control variables } \\
\hline Age & .04 & -.02 & .09 & .05 \\
\hline Slack & -.06 & -.05 & -.11 & -.11 \\
\hline Sector R\&D intensity & -.13 & -.16 & $-.25^{*}$ & $-.24 *$ \\
\hline Adjusted $\mathrm{R}^{2}$ & .22 & .15 & .08 & .09 \\
\hline $\mathrm{F}$ & $6.21 * * *$ & $4.31 * *$ & $3.31^{*}$ & $2.89 *$ \\
\hline
\end{tabular}

$\mathrm{N}=115 ;{ }^{\dagger} \mathrm{p}<.10,{ }^{*} \mathrm{p}<.05, * * \mathrm{p}<.01 ; * * * \mathrm{p}<.001$ 
Table 5: Descriptives for R\&D related activities

\begin{tabular}{rrrrr} 
Variable & Minimum & Maximum & Mean & s.d. \\
\hline Competence additionality & 1 & 7 & 5.16 & 1.24 \\
Network additionality & 1 & 7 & 3.66 & 1.53 \\
Absorptive Capacity firm & & Categorical variable & \\
Absorptive Capacity TI & 2 & 133 & 84.85 & 50.28 \\
Intensity of interaction & 1 & 7 & 3.09 & 1.18 \\
Age (years) & 0.2 & 125 & 26.59 & 20.88 \\
Slack & $-19,598$ & 560,234 & $7,684.87$ & $50,835.78$ \\
Sectoral R\&D intensity & 0.48 & 7.57 & 2.18 & 2.62 \\
\hline
\end{tabular}

$\mathrm{N}=289$

Table 6: OLS regression results for R\&D related activities

Full Model

Mediation Test

\begin{tabular}{|c|c|c|c|c|}
\hline & $\begin{array}{l}\text { Competence } \\
\text { additionality }\end{array}$ & $\begin{array}{r}\text { Network } \\
\text { additionality }\end{array}$ & $\begin{array}{l}\text { Competence } \\
\text { additionality }\end{array}$ & $\begin{array}{r}\text { Network } \\
\text { additionality }\end{array}$ \\
\hline $\begin{array}{l}\text { Independent } \\
\text { variables }\end{array}$ & & & & \\
\hline $\begin{array}{r}\text { Absorptive Capacity } \\
\text { firm (H1a\&b) }\end{array}$ & .03 & .03 & $.14 *$ & $.12^{\dagger}$ \\
\hline $\begin{array}{r}\text { Absorptive Capacity } \\
\text { TI (H2a\&b) }\end{array}$ & $.05^{*}$ & $-.12 *$ & .01 & $-.15^{*}$ \\
\hline $\begin{array}{l}\text { Intensity of interaction } \\
\qquad(\mathrm{H} 3 \mathrm{a} \& \mathrm{~b})\end{array}$ & $.51 * * *$ & $.42 * * *$ & & \\
\hline \multicolumn{5}{|l|}{ Control variables } \\
\hline Age & -.05 & -.02 & .00 & .02 \\
\hline Slack & .01 & .00 & -.01 & -.03 \\
\hline Sectoral R\&D & .00 & .03 & $-.17 *$ & -.11 \\
\hline Adjusted $\mathrm{R}^{2}$ & .25 & .17 & .02 & .02 \\
\hline $\mathrm{F}$ & $11.09 * * *$ & $17.10^{* * * *}$ & $2.19^{\dagger}$ & $2.20^{*}$ \\
\hline
\end{tabular}


Figure 1: Conceptual Framework for R\&D and R\&D related activities

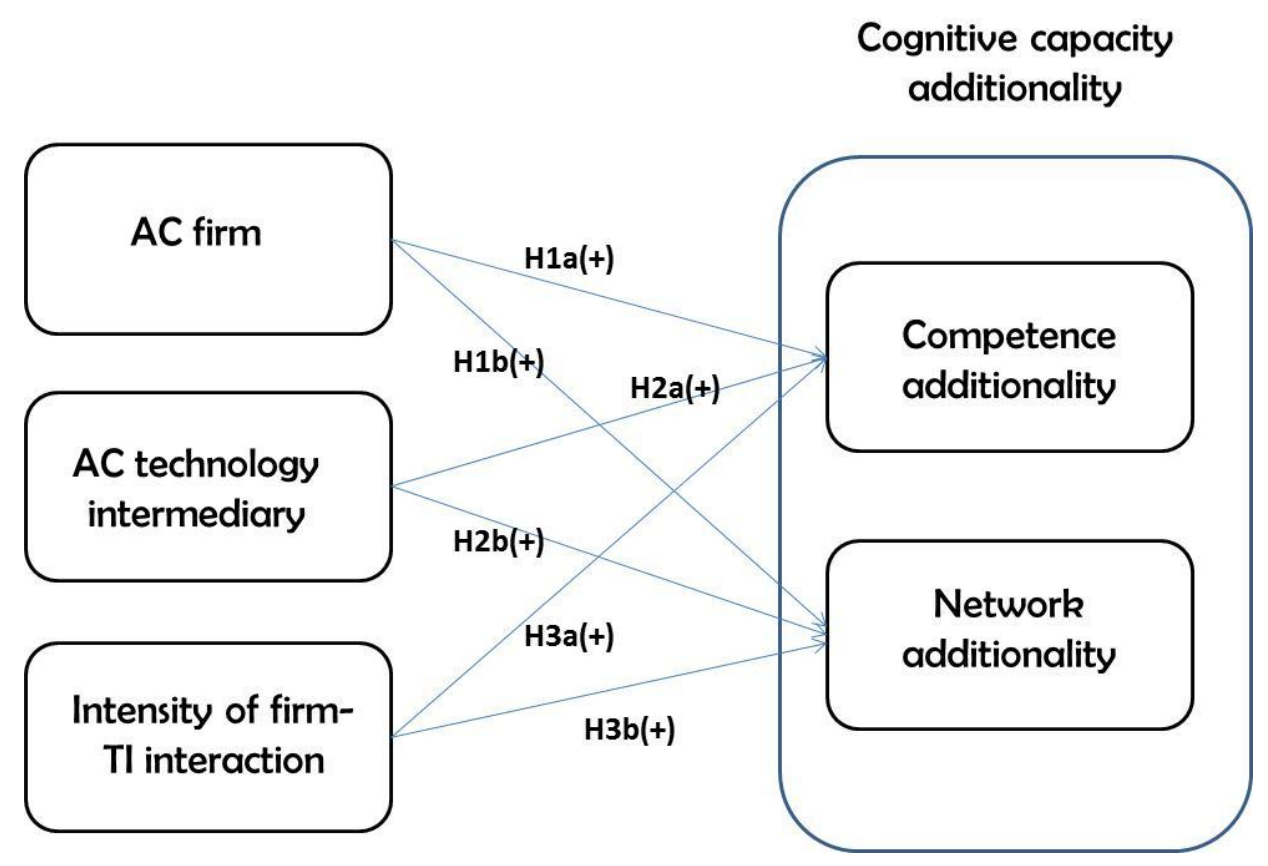

Figure 2: Summary of findings for $R \& D$ and $R \& D$ related activities

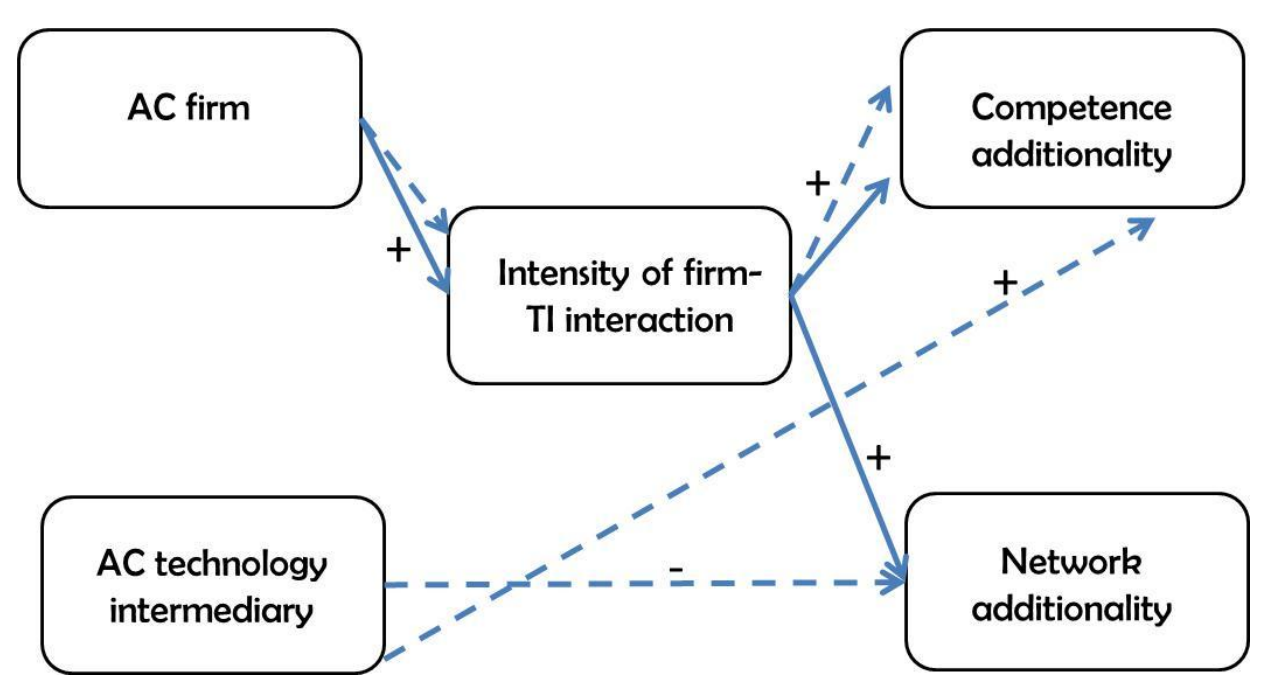

Note: Full arrows for R\&D activities; dashed arrows for R\&D related activities 